\title{
Government's responsibility towards investor's loss in toll development on PPP agreements due to delay in land acquisitions
}

\author{
Dena Zahra Aulia ${ }^{1}$, An-An Chandrawulan², Purnama Trisnamansyah ${ }^{3}$
}

${ }^{1}$ Dena Zahra Aulia; Department of Economical Law, Faculty of Law Padjadjaran University; Jl. Raya Bandung Sumedang; Sumedang; Jawa Barat; 45363; Indonesia.

${ }^{2}$ An-An Chandrawulan; Department of Economical Law, Faculty of Law Padjadjaran University; Jl. Raya Bandung Sumedang; Sumedang; Jawa Barat; 45363; Indonesia.

${ }^{3}$ Purnama Trisnamansyah; Department of Economical Law, Faculty of Law Padjadjaran University; Jl. Raya Bandung Sumedang; Sumedang; Jawa Barat; 45363; Indonesia.

\begin{tabular}{l}
\hline A R T I C L E I N F O \\
\hline Article history: \\
Received 2020-12-13 \\
Received in revised form \\
2021-03-18 \\
Accepted 2021-04-01
\end{tabular}

Kata kunci:

Infrastruktur, Jalan Tol, PPP,

Pengadaan Tanah, Investor.

\section{Keywords: \\ Infrastructure; Toll Road; PPP; Land Procurement; Investors.}

DOI: https://doi.org/10.26905/ idjch.v12i1.4337.

\section{How to cite item:}

Aulia, D. Z., Chandrawulan, AA., Trisnamansyah P. (2021). Government's responsibility towards investor's loss in toll development on PPP agreements due to delay in land acquisitions. Jurnal Cakrawala Hukum, 12(1), 21-31.

doi:10.26905/idjch.v12i1. 4337.

Corresponding Author:

* Dena Zahra Aulia.

E-mail address: Dena16001@mail.unpad.ac.id.

\begin{abstract}
Abstrak
Proyek pembangunan infrastruktur jalan tol masih menjadi salah satu penghambat selesainya suatu proyek pembangunan. Lambatnya proses pengadaan tanah tersebut merugikan pihak-pihak yang terlibat dalam PPP, terutama investor. Penelitian ini menggunakan metode pendekatan yuridis normatif dengan spesifikasi penelitian deskriptif analitis. Teknik pengumpulan data dilakukan dengan cara studi kepustakaan untuk mendapatkan data sekunder dan wawancara untuk mendapatkan data primer, selanjutnya data yang diperoleh akan dianalisis dengan metode yuridis kualitatif yaitu dengan menginventarisir, menyusun secara sistematis, menghubungkan satu sama lain terkait dengan permasalahan yang diteliti dengan berlakunya ketentuan peraturan yang satu tidak bertentangan dengan peraturan lainnya. Hasil dari penelitian ini adalah bentuk tanggung jawab dari Pemerintah akibat dari adanya keterlambatan pengadaan tanah yaitu ganti kerugian berupa perpanjangan masa konsesi pada suatu proyek pengerjaan jalan tol berskema PPP, dan pertimbangan penambahan tarif awal pada jalan tol berdasarkan inflasi, modal, lama pengerjaan konstruksi dan pertambahan masa konsesi dan juga pengenaan denda dalam suatu kontrak bisnis, dan jalan terakhir penyelesaian sengketa perjanjian PPP melalui lembaga non litigasi atau arbitrase berdasarkan Peraturan Presiden Nomor 38 Tahun 2015.
\end{abstract}

\begin{abstract}
Until now, the slow process of land acquisition in toll road infrastructure development projects is still one of the obstacles to the completion of a infrastructure development project. The delay in the land acquisition process is detrimental to parties involved in PPP, especially investors. This study uses a normative juridical ap-
\end{abstract}




\title{
Jurnal Cakrawala Hukum, Volume 12 No. 1 April 2021
}

ISSN PRINT 2356-4962 ISSN ONLINE 2598-6538

\begin{abstract}
proach with analytical descriptive research specifications. Data collection techniques are carried out by means of literature study to obtain secondary data and interviews to obtain primary data, then the data obtained is analyzed using qualitative juridical methods, namely by taking inventory, systematically arranging, connecting with each other related to the problems studied with the enactment of the provisions of the regulations. one does not conflict with other regulations. The result of this research is a form of responsibility from the Government due to delays in land acquisition, namely compensation in the form of extension of the concession period on a toll road project with a PPP scheme, and consideration of additional initial tariffs on toll roads based on inflation, capital, construction time and increase. the concession period and also the imposition of fines in a business contract, and the last resort for resolving disputes over the PPP agreement through non-litigation or arbitration institutions based on Presidential Regulation Number 38 of 2015.
\end{abstract}

\section{Introduction}

In accordance with the fifth Pancasila precepts that read "Social justice for all Indonesian People", currently Indonesia is tightening development in all corners of the Country in order to achieve the goals of the State, namely social justice for all levels of Indonesian society. During the 5 (five) years of President Joko Widodo's and Vice President Jusuf Kalla's administration in 2014-2019, infrastructure development has indeed become a top priority, even to the sustainability of President Joko Widodo's leadership with current Vice President Ma'ruf Amin. So that it can be said the term "infrastructure" itself has been attached to the self-image of the current administration. On various occasions, the President conveyed how important infrastructure is for the progress of a nation, even in a state address at the time of President's inauguration, the status of infrastructure was at number two in the state vision of the 2019-2024 government period.

Development can be defined as "a business or series of efforts for growth and change that are planned and carried out consciously by a nation, state and government, towards modernity in the context of fostering the nation (nation building). Infrastructure can sustain a variety of needs for a country, therefore Infrastructure is an important part as a driver of development and economic growth of a country. Indonesia as a developing country that is incessant in building infrastructure, of course requires a lot of funding, and is greatly helped by the existence of a system of government cooperation with business entities or commonly called the Public Private Partnership Scheme or locally known as KPBU.

PPP schemes are often the leading program because they are often successful in building infrastructure effectively and efficiently. In addition to save state expenditure, there is also a method of sharing of risks in the use of the PPP scheme, which makes it a distinct advantage of PPP. The government is also helped by business entities that have better capabilities and capacities so that infrastructure projects can be handled properly. It cannot be denied that in an infrastructure development project, of course, there are contingent liabilities that must be borne by the government. Contingent government liabilities arising in infrastructure projects are also described in a journal written for the World Bank, which states that (Irwin \& Mokdad, 2010):

"Governments that use public-private partnerships (PPPs) to build infrastructure usually assume contingent liabilities relating, for example, to early contract termination or to debt and revenue guarantees. Deciding whether to assume these liabilities and, if so, determining how to value, 
monitor, and limit them is difficult for most governments."

Public Private Partnerships (PPP) is a popular issue with investors in Indonesia. This PPP scheme is becoming popular because it opens up opportunities for Business Entities to become Investors in infrastructure. The infrastructure facilities can be in the form of road infrastructure, drinking water supply infrastructure, electricity infrastructure, and others. For the government, the PPP scheme is an alternative solution to support the needs of infrastructure spending in accordance with the massive Five-Year Development Plan (RPLT).

The issue of land procurement is still the biggest obstacle in infrastructure development, accounting for $30 \%$ of all infrastructure development problems. The issue of land acquisition is commonly found in various infrastructure projects in Indonesia. Land procurements is a fundamental step in toll road building process, and if the problem of land procurements has not yet been completed, the next stage of development cannot proceed. Problems that arise in land procurement includes the lack of allocation of funds for land procurements and the slow process of land procurements.

The obstacles that arise in the process of land acquisition eventually lead to the "time lag" in a toll development project that spreads to not achieving the target development time, which had been agreed in advance by the two contracting parties, both the government and the company that invested the funds for a development project that could lead into default.

This study aims to analyze the rights of investors in a PPP contract due to the delay of the land acquisition process. Focus on two issues. First, about the form of government's responsibility towards investor's losses due to the delay of land procurement process in PPP Schemed agreements. Second, how is the implementation of government's due to the problem of delays in land procurement.

\section{Method}

The research method in writing this article is a doctrinal research method or what is commonly called normative legal research. This research is a legal research using the socio-normative approach. The data used are primary data and secondary data which were analyzed using quantitative analysis.

\section{Discussion}

\subsection{Brief review on agreements or contracts} in general and PPP agreements in scope of the contractual law

\section{1) Agreements/ contract in general}

The legal scholars gives variety definition of an agreement, according to Sri Soedewi, an agreement is a legal act in which one or more refers himself to someone else or more (Sofwan, 1982). According to M. Yahya Harahap, what is meant by agreement is a legal relationship that concerns the law of wealth between 2 (two) or more people, which gives rights to one party and obligations to another party regarding an achievement (Harahap, 1986). Subekti (2003), states that an agreement is an event someone promises to another person or two people that promise to do something, from this event an engagement arises. The definition of the agreement is also regulated in Article 1313 of the National Civil Code (KUHPerdata), the contents of the article read: "An agreement is an act with which one or more people bind themselves to one or more other people". Article 1313 of the Civil Code confirms that an agreement results in a person binding himself to another person.

The Civil Code does not provide a comprehensive definition or understanding of the engagement, only as stated in Article 1233 it is explained that "The Agreement was born because of an agreement or because of the Law". Subekti provides the definition of an agreement, namely a 
relationship between two people or two parties based on which one party has the right to demand something from the other party is obliged to fulfill the demand. Thus it can be concluded the elements of the engagement, namely: 1) There is a legal relationship; 2) Between two parties, the party that has the obligation (debtor); 3) Being in the field of property law; 4) The goal is achievement; 5) There are those who argue that an agreement is not the same as an agreement.

A contract or agreement to be said to be binding and in effect must first fulfill the legality requirements of the agreement as determined by law, namely agreement, skills, certain matters and a lawful cause, as determined in Article 1320 of the Civil Code. The four conditions are: 1) Agree to those who entered into an agreement; 2) Ability to make agreements; 3) A certain thing; 4) A lawful cause.

\section{2) Tort and compensations in agreements/ contract}

Torts are derived from the original Dutch term "wanprestatie" which means that the achievements or obligations that have not been fulfilled for certain parties in an agreement have not been fulfilled, either an agreement that was born from an agreement or an agreement that arises because of the Act (Abdulkadir, 2000). Furthermore, Torts are regulated in Article 1243 of the Civil Code, which is as follows: Reimbursement of costs, losses and interest due to non-fulfillment of the engagement has begun to be compulsory, if the debtor, even though it has been declared negligent, remains negligent to fulfill the engagement, or if something that must be given or done can only be given or done in a time that exceeds the specified time.

If the debtor does not do as what was promised, then he is said to have tort. He is negligent or negligent or broken promises. Or he also violates the agreement, if he does or does something he is not allowed to do. Defaults bring legal consequences, namely the obligation for debtors to pay compensation or with a default by one party, the other party may demand the cancellation of the agreement as can be seen from the Supreme Court Decision of 21 May 1973 No. 70HK / Sip / 1972 which states that if one of the parties defaults on the failure to pay for the goods purchased, the injured party may demand the cancellation of the agreement. According to Article 1243 of the Civil Code, the definition of compensation in civil law places more emphasis on compensation because an agreement is not fulfilled, namely the debtor's obligation to compensate the creditor for losses due to negligence of the debtor to default. These damages include: 1) Costs or costs that have been incurred; 2) Actual losses due to damage, loss of items belonging to the creditor due to debtor's negligence; 3) Expected interest or profit.

Furthermore, what is meant by loss is loss due to damage to goods belonging to the creditor due to negligence of the debtor. For example, in the case of buying and selling cows. If the cow he bought contains a disease which is contagious to the other cows belonging to the buyer, so that these cows die from the disease. Or, the house that was just handed over by the contractor collapsed due to the wrong construction, destroying all the furniture in the house. Meanwhile, what is meant by interest is a loss in the form of loss of profit (winstdervig) that has been imagined or calculated by the creditor (Slamet, 2013).

\subsection{Compensations to investors as a result of the delay of land acquisitions in toll road projects using the PPP scheme}

\section{General overview of PPP scheme in in- frastructure development in Indonesia}

Indonesia is known as a large country with a land area of 1,904,569 square kilometers, is the 14th largest country in the world. The rank rises 
to be the 7th largest country in terms of land and sea, this country consists of 34 provinces. Indonesia's population - which reaches 261 million makes it the most populous country in the world, and the most populous in Southeast Asia. According to the World Bank, Indonesia's GDP per capita continues to increase, from $\$ 857$ in 2000 to $\$ 13,120$ in 2017 . Indonesia is a member of the G-20 which is a representative of developing countries that provide the world economy (World Bank, 2020). Because of its large size and population, the Government of Indonesia will require an investment of USD 359.2 billion for infrastructure development. However, it is estimated that only $73.5 \%$ of the investment value will be provided through the State Budget and State-Owned Enterprises projects.

\section{Problems faced in the construction of toll roads in Indonesia through the PPP scheme}

a. Complex land procurement process

Land ownership is often a problem in the land procurement process. Especially, in the case of colonial land ownership, which is a land that is prone to disputes. For example, land in the Jatinangor area affected by the Cisumdawu Toll Road project was sued through the Sumedang District Court, which was registered in Case Number No. 3 / PDT.G / 2017PN.Smd on February 16, 2017. The plaintiff has proof of legal ownership of the exJatinangor plantation area of 1970 hectares in the form of Eigendom Verponding (title) deed No. 3 which has been authenticated by BPHN Ministry of Law and Human Rights on December 22, 2012 and has been determined based on the determination of the Sumedang Religious Court No. 156 / Pdt.P / 2013 / PA Smd on November 19, 2013. So, with the existence of evidence of ownership by the defendant, the land in the Jatinangor Region, in addition to being disputed with institutions and local residents who first occupied the land without knowing the origin of the owner, also increasingly complicating land procurement for public use.

b. Unprepared budget from the government for project work

Limited funds from the State Revenue and Expenditure Budget (APBN) / Regional Revenue and Expenditure Budget (APBD) also become one of the problems in infrastructure development, for example, in one year it is budgeted 300 billion to work on a project but it turns out that in the field the value of the development project is more large and not in accordance with the budgeted, then have to wait for funds budgeted the following year (in Bappeda, West Java Province).

c. Local government unpreparedness

A project whose certainly involves certain areas that are more specific in its work. However, there are times when the Regional Government is 'not ready' to work on the project, one of which is the establishment of the South Banten Airport, which was excluded from the National Strategic Project (Prolegnas) because the Pandeglang District Government is not ready. This can be seen from the impropriety of the Pandeglang Regency Government in preparing the administration and economic valuation of the land which is used as a national strategic project area (Mukson, 2020).

d. Social problems

Other problems that must be faced are social problems, such as lack of funds for compensation to landowners due to appraisal that is requested by residents whose land is affected so as to cause demonstrations or lawsuits by residents. One of the public facilities affected by the construction of this project is the AlFalah Mosque, a mosque located in Kampung Parung Beunying, RT 004 RW 03, Sarua, Ciputat, South Tangerang. Residents who 
worship at the mosque are disturbed because the place is dirty and the noise from the project machine. Although the mosque's resettlement (relocation) and the provision of replacement land (ruislah) for new mosque land and buildings have not been provided, the construction of the toll road project continues (Haryanto, 2012).

e. Business entities threatened to bankruptcy due to debt entwined for infrastructure funding Technically Bankrupt is when the assets owned by a company are equal to the total debt, if it is like that then it means that the ratio of debt that is borne is compared to the assets owned by which the company can be bankrupt. At present, there are 4 BUMN BUMNs that are Technically Bankrupt because they are wrapped in short-term debt to finance infrastructure projects assigned by the government. 4 BUMN Karya which has been assigned by the government to work on infrastructure projects is wrapped in a term debt of IDR156 trillion, of which IDR115 trillion is a short-term debt that must be repaid within 1 year (dpr.go.id, 2020).

Another case occurred in working on the Umbulan Water Supply System (SPAM) project, PT Meta Adhya Tirta Umbulan, which was in debt and was facing a lawsuit for Deferring Debt Payment Obligations in the Surabaya Commercial Court. The company, which was built by a consortium of PT Medco Gas Indonesia and PT Bangun Cipta Kontraktor, is facing a request for a Postponement of Debt Payment Obligations (PKPU) of Rp25,436,327,015 from two creditors. The first creditor was PT Orbarador with a debt bill that was due at $520,595.50$ US dollars or Rp7,324,251,055 (exchange rate of Rp14,069 / US dollar) and amounting to Rp13,106,161,560 plus 1.2 percent interest per month starting April 11 2019. Second, is PT. Rukun Mandiri Jaya with a maturing debt of Rp5,005,914,400 plus an interest of $1.2 \%$ per month starting April 11, 2019. The PKPU request was registered with Cahaya Muda Kreasi in the Commercial Court of Surabaya with case number 22 / Pdt.Sus-Pailit / 2019 / PN on Monday, October 14, 2019 (tirto.id, 2020).

\section{Problems of land acquisition as a cause of delay in the construction of a toll road construction project}

Land is a crucial element in a toll road buiding project, where the results of the development are intended to meet and improve people's welfare. However, the process of land acquisition or land acquisition for development on the grounds of public interest is still one of the obstacles to the completion of a development project. Most of the land has become individual and group assets, which of course have their own interests in the land. The issue of land acquisition has become an issue that is considered daily.

In addition, problems related to compensation for land acquisition for surrounding residents still dominate. Even the people whose land will be used for public purposes sometimes feel that the compensation given by the Government is still too little than they expected, whereas the Government feels that the compensation value is in accordance with the calculation. This becomes the host of problems between the Government and some communities in providing compensation for land acquisition.

The existence of various interests that seem contradictory between one party and another related to land issues in development causes the process of land acquisition for development interests to become unresolved and protracted. On the one hand, development really requires land as its main means, while on the other hand most of the community members also need the land as a place of settlement and a place of livelihood. If the land is 
taken for granted and used for government purposes, it means sacrificing the human rights of citizens who should not have happened in a country that adheres to the "Rule of Law" principles. However, if left unchecked it will also have an impact on stalled development efforts (Herlinda, 2004).

Other impacts resulting from the delay in land procurement are: 1 . Impacts on Construction; such as Construction Delay and Swelling of construction tariffs; 2. Social Impacts; 3. Environmental Impacts.

\section{Implementation of compensation for land procurement lateness}

One case example of late land procurement that affects the course of a project construction is found in the Cileunyi-Sumedang-Dawuan Toll Road Project (Cisumdawu). The reason for the delay in land acquisition was the lack of agreement on the amount of land compensation from the surrounding residents. Because there was no agreement on the price of the land to be released, the government provided compensation through the court (consignment). However, the time span from socialization with surrounding residents will be the acquisition of land in the public interest, the determination of the value of compensation, deliberation and mediation with residents until finally the consignment requires a lot of time and a very long process. Finally, due to the slow process of land acquisition, resulting in interest from loan funds from investors increasingly swell. The government uses APBN funds in the amount of 1 Trillion Rupiah, and uses loan funds in the amount of 3.7 Trillion Rupiah (Harimurti, 2020).

Toll Road Business Entity (BUJT) which also worked on the toll road certainly uses its own capital, namely in the project using investment funds worth 5.8 Trillion. The consideration is, BUJT uses the loan fund (loan) fully, which of course the loan is 'one package' with interest. As a result of the slow process of land acquisition, of course it is very burdensome to the BUJT, because the cost of construction to interest is getting bigger. The government as the project owner should be responsible for the process of delay in land acquisition which is detrimental to the investor (BUJT) (PT Citra Karya Jabar Tol, 2020).

\subsection{The implementation of government's re- sponsibility to investor companies due to the lateness of land procurement in the development of toll roads through PPP schemed agreements}

\section{Forms of government responsibility} against losses corporate investors in infrastructure development due to delays in land procurement

The postponement of the land procurement process is something that can be estimated when an agreement is made, and therefore when there is a delay, responsibility is needed because it impacts the overall toll road infrastructure development process, both socially, financially as well as the target of the completion of an ongoing project. However, known causes of delays in land acquisition are usually due to complex land acquisition systems, or because the land to be acquired is disputed land. The BUJT itself often objected to the delays in land acquisition because it caused losses in the form of operating time to financial.

The delay in land procurement can become a default if the PPJT contains a land acquisition target agreed by the parties but is not achieved due to problems such as the complexity of the land acquisition process. If in the performance of the achievement the grace period is not determined, then a creditor or party who has the right to receive achievements in the contract (in this case the Investor), is deemed necessary to warn / reprimand so that the debtor or other parties who have 
the obligation to carry out the achievements in the contract to fulfill their obligations. This reprimand is also called summation (sommatie). In the Cisumdawu toll development project the government has the responsibility to carry out land acquisition. However, in reality it is not as easy as a land acquisition process. Barriers such as government budget constraints result in the intervention of Business Entities in funding land acquisition.

a. Responsibility given by the government to business entities for losses on late procurement Based on the results of interviews conducted with resource persons namely as a Legal $\mathrm{Bu}-$ reau at PT CKJT, In general, if there is a problem in the agreement that results in material losses to the company, then the method of resolution is through consultation between the parties, before going to court. Based on the form of losses suffered by the Business Entity as explained above, the responsibilities that can be given by the Government to the Business Entity are as follows (Citra Karya Jabar Tol, 2020):

1) Extension of Concession Period

In general, the definition of tariff is the fee or fees paid to obtain goods or services. So in this case the toll tariff is the cost that must be incurred by toll road users to pay for toll road services (in this case usage services) and therefore get the benefits as a result of receiving these services.

Basically, toll roads are built with the intention of reducing vehicle operating costs, which may be caused by shorter road lengths and higher average vehicle speeds so that time savings occur. On the other hand, toll revenues are used for investment returns, operation and maintenance, as well as for further toll road development. For this reason, toll rates are calculated based on the ability to pay road users, the amount of profit in vehicle op- erating costs, and investment feasibility. The enactment of toll rates is determined simultaneously with the stipulation of road operations as toll roads. Evaluation and adjustment of toll rates are carried out every 2 (two) years based on the old tariffs adjusted to the effects of inflation according to the formula (Law No. 38/2004 article 48 paragraph (3), PP 15/2005 article 68 paragraph (1) (Hermawan, 2020).

2) Initial tariff increase

The government experiences limitations in developing toll roads, and involves the private sector through cooperation between the Government and Business Entities. The implementation of toll road investment is constrained by land acquisition and the risk of reducing investment feasibility. There is a relationship between land acquisition and initial rates, through investment costs, operation / maintenance, and traffic volume. Tariff adjustment is an alternative to maintain investment feasibility from land acquisition uncertainty. The Cinere-Jagorawi toll road which uses the BOT scheme is one of the case studies for the development of modeling / simulation of the time of land acquisition against the initial tariff adjustment, the results of which are that every year land delays reduce $0.35 \%$ of investment feasibility equivalent to an increase in tariffs of 30 Rupiah / $\mathrm{km}$ or an increase of $4 \%$ from the previous rate (Darmawan, 2012).

3) Fine formed sanctions

In an agreement, a clause can be proposed, which is about fines, if there are things which are the obligations of one party but are not implemented. The amount of the fine can be determined by the parties by agreement, and will be charged if one party does not fulfill what was promised 
in the agreement. With the responsibility given by the Government, it can be a form of compensation by the Government to the parties that are harmed by the delays in land procurement, namely the Investor or BUJT.

\section{The implementation Government's re- sponsibility as the form of compensation to investors in infrastructure develop- ment due to delay in land procurement PPP schemed agreements}

After an agreement has been formed and agreed upon, the responsibility arises to each party who binds itself to the agreement. In the legal dictionary, responsibility is a must for someone to carry out what is required of him. If there is a default in the process of developing toll road infrastructure, the default contract must be included in the Toll Road Concession Agreement (PPJT).

For example, in the Semarang-Solo Toll Road construction project, the default clause is listed as follows: 1 . The toll road company transfers or gives all or part of its rights in this agreement except in connection with the transfer or granting of rights under this agreement; 2. A toll road company is declared disbanded based on a decision of the general meeting of shareholders of the road company or; 3 . Toll road companies are declared bankrupt or insolvent, or; 4 . Toll road companies apply for bankruptcy or insolvency or; 5 . The toll road company changes its purpose and objectives in the articles of association of the toll road that are not in accordance with the purpose of the toll road concession; 6 . Toll road companies violate a statement and guarantee in accordance with this agreement or other statements and guarantees as stipulated in the legislation; 7 . There are changes in the shareholders and the composition of the shareholders of the toll road company unless as stated otherwise based on this agreement; 8. Toll road company carries out an activity or business activity outside of toll road concession without prior written government approval.

If there is a default or broken promise in the construction of a toll road under the PPP scheme, the government can take the actions set out in the PPJT. In this case, the writer takes one example of a case, the Semarang-Solo toll road development project case. In the case of the development project, the parties included a follow-up to the termination of the agreement, which can take over and continue the concession of the toll road and reauction if the contractor carries out a default. The toll road concession agreement (PPJT) also emphasizes the obligations and responsibilities of the Toll Road Company, which is to be responsible for any violations of the obligations and responsibilities arising from the actions and failures of each contractor (in this case a Business Entity). Generally in an effort to settle disputes and / or differences in any form that arises between the Government and the Toll Road Company. PT. Trans Marga Central Java in connection with and / or as a result of the agreement.

Based on Article Number 32 subsection no 2 point K Presidential Regulation Number 38 Year 2015, the mechanism of dispute can be solved by discussion, mediation and arbitration/court. Most of the toll projects are using the arbitration because it is more flexible, simple and private. However, not only applies to the Toll Road Business Entity, in a dispute or dispute in the agreement, the Government can also be sued. The government gives the right to those who feel aggrieved to solve it through litigation and non-litigation, depending on the agreement of the parties. So the government basically relinquishes its immune rights. This means that the government can be sued. Settlement of disputes in PPP cooperation contracts usually relies on the process of deliberation designating arbitration as a way out of an issue because it is private or confidential. 


\section{Jurnal Cakrawala Hukum, Volume 12 No. 1 April 2021}

ISSN PRINT 2356-4962 ISSN ONLINE 2598-6538

Usually, deliberations related to dispute resolution are carried out within 60 (sixty) days (may vary by agreement). Then in the agreement it was also confirmed if it could not be completed within 60 days of the deliberations, the parties agreed to settle the dispute through the arbitration process of BANI (Indonesian National Arbitration Board) in accordance with the provisions of Law No. 30 of 1999 concerning Arbitration and Alternative Dispute Resolution.

Disputes that occur in general are usually mostly resolved by arbitration institutions. Arbitration is a way to settle a civil dispute outside the general court based on an arbitration agreement made in writing by the parties to the dispute. The statutory provisions concerning arbitration institutions in Indonesia are regulated in Law Number 30 of 1999 Concerning Arbitration and Alternative Dispute Resolution. Arbitration institutions have advantages compared to judicial institutions. These advantages include the following:

Effective and efficient use of time: The time spent on the arbitration process is more efficient and flexible because the arbitrator is chosen by the parties to the dispute, and then the trial process will be led by the arbitrator, in which case the arbitrator can freely determine the agenda of the trial by adjusting the time of the litigants. When compared to disputes that are resolved through the court, a problem can only be resolved if it has followed court procedures such as processing the case, appointing a judge, and making summons to the disputing party, which will result in a longer case resolution.

\section{Conclusion}

On toll development projects, the government has the responsibility to carry out land procurements. However, in reality, the land acquisition process is not as easy as it seems. Barriers such as government budget constraints result in the intervention of Business Entities in funding land procurements. This study discusses the problems faced in infrastructure development carried out through the PPP agreement, especially the problem of delays in land procurement that impedes the construction of a toll road project. As it is already explained in this article, this research analyzes the responsibility that can be given by the government to the injured party (investor), in the form of an extension of the concession period, addition of the initial toll road tariff or can be in the form of fine-formed sanctions. These problems are resolved through arbitration tribunals which are effective and efficient, cost effective, flexible, confidential and have final and binding decisions.

\section{References}

Abdulkadir, Muhammad. 2000. Hukum Perdata Indonesia. Citra Aditya Bakti. Bandung.

Commercial Court of Surabaya with case number 22 / Pdt.Sus-Pailit /2019/PN Sub.

Commission 5 of The House of Representatives of The Republic of Indonesia. 2020. http://dpr.go.id/ accessed on 11th of March.

Darmawan, Yudhi. 2012. Dampak Ketidak Pastian Waktu Pembebasan Tanah Terhadap Besaran Tarif Awal Pada Proyek Investasi Jalan Tol. Universitas Indonesia Digital Library. Depok.

Friana, Hendra. 2020. https://tirto.id/penggarapproyek-spam-umbulan-terlilit-utang-danterancam-pailit-ejMp, accessed on 11th of March 2020.

Harahap, M. Yahya. 1986. Segi-Segi Hukum Perjanjian. Alumni. Bandung.

Haryanto, F. Kristifiani. 2019. Pemindahan Rumah Ibadah Dan Fasilitas Umum Akibat Pengadaan Tanah Untuk Pembangunan Jalan Tol Berdasarkan Undang - Undang Nomor 2 Tahun 2012 Tentang Pengadaan Tanah Bagi Pembangunan Untuk Kepentingan Umum, Jurnal Hukum Adigama. p. 5.

Herlinda, Erna. 2004. Peranan Pemerintah Atas Tanah Dalam Rangka Pembangunan. Fakultas Hukum Universitas Sumatera Utara: USU Digital Library, p. 2. Sumatera Utara. 
Hermawan, Rudy. 2020. Kaji Ulang Penentuan Tarif dan Sistem Penggolongan Kendaraan Jalan Tol di Indonesia. Jurnal Teknik Sipil: Jurnal Teoretis dan Terapan Bidang Rekayasa Sipil.

Irwin, Timothy \& Mokdad, Tanya. 2010. Managing Contingent Liabilities in Public Private Partnerships: Practice in Australia, Chile, and South Africa. World Bank Report 101491. Januari 2010. p. vii.

Law No. 2 of 2012 Concerning Land Procurement for Development in the Public Interest.

Law No. 30 of 1999 Concerning Arbitration and Alternative Dispute Resolution.

National Civil Law of the Indonesian Republic.

Presidential Regulation Number 38 of 2015 Concerning Cooperation of The Government and Business Entities In Infrastructure Provision.

Presidential Regulation Number 71 of 2012 Concerning Provision of Land Procurement for Development in Interests General and / or other related regulations.

Raharjo, Dwi Bowo. 2020. https://www.suara.com/accessed on 11th of March.

Redaksi Banten Headline. 2020. https:/ / bantenheadline.com/ minim-progres-pemkab-pandeglang-dinilai- lambat-tindak-lanjut-program-nasional/ Accessed on 11th of March 2020.

Republic of Indonesia. 2018. Public-Private Partnerships: Infrastructure Projects Plan in Indonesia. Journal BAPPENAS. Ministry of National Development Planning/ National Development Planning Agency. pp. vi.

Slamet, Sri Redjeki. 2013. Tuntutan Ganti Rugi Dalam Perbuatan Melawan Hukum: Suatu Perbandingan Dengan Wanprestasi, Jurnal Lex Jurnalica. Volume 10 Nomor 2, Agustus, hlm. 114.

Sofwan. \& Soedewi, Sri. 1982. Hukum Perjanjian. Universitas Gadjah Mada. Yogyakarta.

Subekti. 2003. Pokok-Pokok Hukum Perdata. Cetakan ke31. Intermasa. Jakarta.

Sumedang District Court, Case No. 3 / PDT.G / 2017PN.Smd.

Sumedang Religious Court, Case No. 156 / Pdt.P / 2013 / PA Smd.

The World Bank. 2020. https://www.worldbank.org/ en/country /indonesia/ overview, accessed on 4th of January 2020. 